\title{
Adjuvant Hormonal Treatment for Prostate Cancer: The Bicalutamide Early Prostate Cancer Program
}

\author{
Manfred P. Wirth Michael Froehner \\ Department of Urology, University Hospital 'Carl Gustav Carus', Technical University of Dresden, \\ Dresden, Germany
}

\section{Key Words}

Prostate cancer - Adjuvant - Hormonal treatment . Bicalutamide - Radical prostatectomy - Radiotherapy • Watchful waiting

\begin{abstract}
Adjuvant hormonal therapy has been demonstrated to be able to delay disease progression in nonmetastatic prostate cancer. To date, however, a favorable impact on survival has only been demonstrated in lymph-nodepositive disease and in external-beam radiotherapy series with locally advanced and probably mainly micrometastatic tumors. The Bicalutamide Early Prostate Cancer Program is the largest study under way to define the role of adjuvant treatment in early prostate cancer and identify subgroups of patients likely to benefit from immediate hormonal therapy. At the time of the most recently published analysis, the risk of objective clinical progression was significantly reduced in the bicalutamide arm (hazards ratio 0.58, 95\% confidence interval $0.51-0.66, p<0.0001)$. However, further maturation of data is needed to see whether this difference will lead to a survival advantage.
\end{abstract}

Copyright @ 2003 S. Karger AG, Base

\section{Adjuvant Treatment for Prostate Cancer}

If prostate cancer is organ confined, radical prostatectomy achieves disease-specific 10-year survival rates of about $90 \%$ [1]. There are, however, subsets of patients with a markedly less favorable outcome. When disease has spread outside the prostate, survival is compromised. In a multicentric study with 298 stage cT3 patients treated by pelvic lymph node dissection with or without subsequent radical prostatectomy, the prostate cancerspecific 10-year survival rate was only 57\% [2]. Radiotherapy alone for locally advanced prostate cancer produced unfavorable results as well [3]. Whereas the longterm outcome after radical prostatectomy is excellent in tumors with a Gleason score of 2-6, the disease-specific 15 -year survival is clearly compromised when the Gleason score is 7-10 [4]. In the especially problematic subgroup of patients with Gleason score 8-10 disease, disease-specific 15-year survival after radical prostatectomy is less than 50\% [4]. Several clinical trials investigated the effect of adjuvant hormonal therapy to improve these results. Generally, to date, a favorable impact of adjuvant hormonal treatment on survival has only been demonstrated in lymph-node-positive disease and in external-

Professor Manfred P. Wirth is principal investigator of the 'Bicalutamide Early Prostate Cancer Program' which is supported by AstraZeneca.

\begin{tabular}{ll}
\hline KARGER & ( ) 2003 S. Karger AG, Basel \\
0030-2414/03/0655-0001\$19.50/0 \\
$\begin{array}{l}\text { Fax + 4161306 12 34 } \\
\begin{array}{l}\text { E-Mail karger@karger.ch } \\
\text { www.karger.com }\end{array}\end{array}$ & $\begin{array}{l}\text { Accessible online at: } \\
\text { www.karger.com/ocl }\end{array}$
\end{tabular}

Manfred P. Wirth, Professor and Chairman

Department of Urology, University Hospital 'Carl Gustav Carus'

Technical University of Dresden

Fetscherstrasse 74, DE-01307 Dresden (Germany)

Tel. +49 351 4582447, Fax +49 351 4584333, E-Mail wirth-m@rcs.urz.tu-dresden.de 
Table 1. Overview over selected studies on adjuvant hormonal treatment after curative therapy for prostate cancer

\begin{tabular}{|c|c|c|c|c|c|c|}
\hline Authors & Year & Setting & $\begin{array}{l}\text { Inclusion } \\
\text { criteria }\end{array}$ & $\begin{array}{l}\text { Hormonal } \\
\text { treatment }\end{array}$ & Progression & Survival \\
\hline $\begin{array}{l}\text { Pilepich et al. [5] } \\
\text { Lawton et al. [6] }\end{array}$ & $\begin{array}{l}1997 \\
2001\end{array}$ & RT & stage $\mathrm{C}$ or $\mathrm{D} 1$ & LHRH analogues & $\begin{array}{l}\text { advantage for } \\
\text { adjuvant treatment }\end{array}$ & $\begin{array}{l}\text { advantage for adjuvant treatment in } \\
\text { Gleason score } 8-10 \text { subgroup }\end{array}$ \\
\hline Granfors et al. [7] & 1998 & RT & $\mathrm{T} 1-4 \mathrm{~N} 0-1$ & orchiectomy & $\begin{array}{l}\text { advantage for } \\
\text { adjuvant treatment }\end{array}$ & $\begin{array}{l}\text { advantage for adjuvant treatment in } \\
\text { N1 subgroup }\end{array}$ \\
\hline Arcangeli et al. [8] & 1998 & RT & $\begin{array}{l}\text { confined to } \\
\text { the pelvis }\end{array}$ & multiple regimens & $\begin{array}{l}\text { no advantage for } \\
\text { adjuvant treatment }\end{array}$ & disadvantage for adjuvant treatment \\
\hline Hanks et al. [9] & 2000 & RT & $\begin{array}{l}\mathrm{T} 2 \mathrm{~b}-\mathrm{T} 4 \\
\mathrm{PSA}<150 \mathrm{ng} / \mathrm{ml}\end{array}$ & $\begin{array}{l}\text { LHRH analogues } \\
\text { plus flutamide }\end{array}$ & $\begin{array}{l}\text { advantage for } \\
\text { adjuvant treatment }\end{array}$ & $\begin{array}{l}\text { advantage for adjuvant treatment in } \\
\text { high risk subsets (cT3-4 or cT2 with } \\
\text { Gleason score } 8-10 \text {, } \\
\text { all Gleason score } 8-10 \text { cancers) }\end{array}$ \\
\hline Bolla et al. [10] & 2002 & RT & $\mathrm{T} 1-\mathrm{T} 4 \mathrm{~N} 0-\mathrm{x}$ & LHRH analogues & $\begin{array}{l}\text { advantage for } \\
\text { adjuvant treatment }\end{array}$ & advantage for adjuvant treatment \\
\hline Zincke et al. [11] & 1992 & RPE & $\mathrm{pN}+$ & multiple regimens & $\begin{array}{l}\text { advantage for } \\
\text { adjuvant treatment }\end{array}$ & $\begin{array}{l}\text { advantage for adjuvant treatment in } \\
\text { diploid subgroup }\end{array}$ \\
\hline Seay et al. [12] & 1998 & RPE & $\mathrm{pN}+$ & $\begin{array}{l}\text { orchiectomy or } \\
\text { LHRH analogues }\end{array}$ & $\begin{array}{l}\text { advantage for } \\
\text { adjuvant treatment }\end{array}$ & $\begin{array}{l}\text { advantage for adjuvant treatment in } \\
\text { diploid subgroup after } 10 \text { years }\end{array}$ \\
\hline Messing et al. [13] & 1999 & RPE & $\mathrm{pN}+$ & $\begin{array}{l}\text { orchiectomy or } \\
\text { LHRH analogues }\end{array}$ & $\begin{array}{l}\text { advantage for } \\
\text { adjuvant treatment }\end{array}$ & advantage for adjuvant treatment \\
\hline Prayer-Galetti et al. [14] & 2000 & RPE & stage $\mathrm{C}$ & LHRH analogues & $\begin{array}{l}\text { advantage for } \\
\text { adjuvant treatment }\end{array}$ & not available \\
\hline Zincke et al. [15] & 2001 & RPE & $\begin{array}{l}\text { seminal vesicle } \\
\text { involvement }\end{array}$ & $\begin{array}{l}\text { orchiectomy or } \\
\text { oral hormones }\end{array}$ & $\begin{array}{l}\text { advantage for } \\
\text { adjuvant treatment }\end{array}$ & advantage for adjuvant treatment \\
\hline $\begin{array}{l}\text { Wirth et al. [16] } \\
\text { Wirth et al. [17] }\end{array}$ & $\begin{array}{l}1997 \\
2003\end{array}$ & RPE & stage $\mathrm{C}$ & flutamide & $\begin{array}{l}\text { advantage for } \\
\text { adjuvant treatment }\end{array}$ & no detectable difference \\
\hline
\end{tabular}

$\mathrm{RT}=$ Radiotherapy RPE = radical prostatectomy.

beam radiotherapy series with locally advanced and probably mainly micrometastatic tumors (table 1 ). Adjuvant treatment after the resection or destruction of all macroscopic tumor tissue is intended to prevent progression of suspected microscopic residual cancer. During the last decades, new means of hormonal deprivation (LHRH analogues, antiandrogens) have been developed which allow for reversible and time-limited treatment. Since even in incurable locally advanced or metastatic prostate cancer, immediate hormonal treatment offers only a small survival advantage over deferred treatment after 10 years - detectable only in a meta-analysis including more than 2,000 patients [18] - trials investigating the effect of adjuvant treatment in early prostate cancer require very large numbers of patients enrolled and a long follow-up. The optimal duration of adjuvant treatment and the question whether delayed onset of hormonal treatment (controlled by PSA monitoring) may be as effective as immediate treatment in risk patients [19] remain the subject of an ongoing debate.

\section{The Bicalutamide Early Prostate Cancer Program}

In early breast cancer, adjuvant treatment with the antioestrogen tamoxifen resulted in a significant survival benefit over local therapy only [20]. Since prostate cancer is also a hormone-sensitive tumor, it has been hypothezised that early antiandrogenic therapy may be beneficial in this tumor entity as well $[21,22]$. In the 'Bicalutamide Early Prostate Cancer Program' (for clinical stages T1b$4 \mathrm{~N} 0-1 \mathrm{M} 0$ ), the nonsteroidal antiandrogen bicalutamide is being evaluated as primary or adjuvant therapy for early prostate cancer. The program consists of three doubleblind, parallel-group trials (one in North America (trial 23, $n=3,292)$, one in Mexico, South Africa, Australia and Europe (trial 24, $n=3,603$ ), and one in Scandinavia (trial $25, \mathrm{n}=1,218$ ) [22]. In trial 23, all patients underwent radical prostatectomy or radiotherapy prior to study entry. In trials 24 and 25, watchful waiting was possible as a primary management option besides both treatments with cura- 


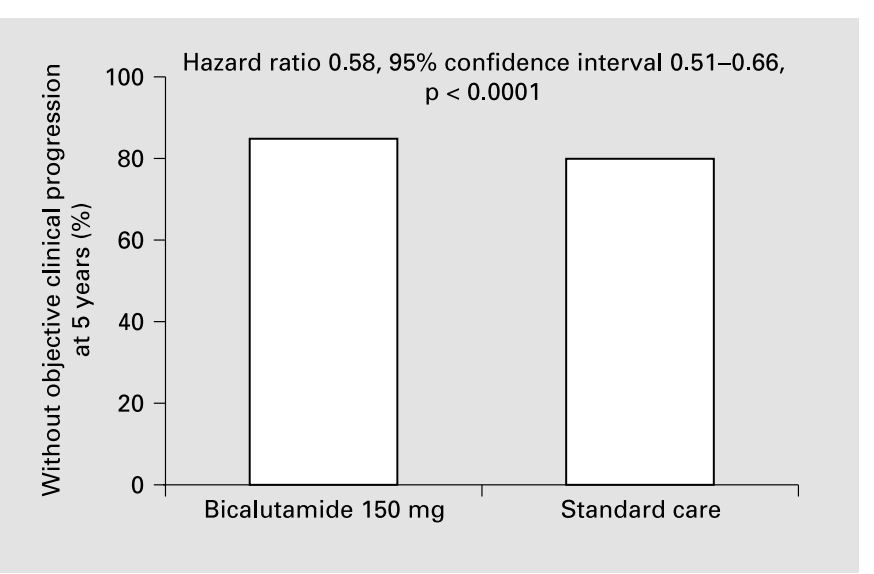

Fig. 1. Freedom from objective clinical progression at 5 years [22].

tive intent $[21,22]$. For an exact description of the inclusion and exclusion criteria, see See et al. [22]. With a total of 8,113 patients, this program is the largest currently ongoing study on prostate cancer [23]. The patients were randomized on a 1:1 basis to receive either bicalutamide $150 \mathrm{mg}$ once daily $(\mathrm{n}=4,052)$ or placebo $(\mathrm{n}=4,061)$ [22]. In North America, more than $80 \%$ had undergone radical prostatectomy and $20 \%$ received radiotherapy prior to randomization, compared to 46 and $18 \%$ in the Mexico, South Africa, Australia and Europe trial and 13 and 5\% in the Scandinavian trial [22]. In North America, more than $70 \%$ of patients entered had a tumor stage of less than T3, compared with approximately $60 \%$ in Europe and Scandinavia [22-24]. The patients received the adjuvant medication for 2 or more years [22]. Time to objective clinical progression (defined as tumor progression confirmed by either biopsy, bone scan, computerized tomography, ultrasound, or magnetic resonance imaging or death of any causes) and survival are the primary end points in the Bicalutamide Early Prostate Cancer Program [21, 22]. Time to treatment failure (withdrawal from treatment), PSA progression (defined as doubling of the PSA value measured immediately prior to the initiation of the application of the study medication) and tolerability are secondary end points [21,22]. After a median follow-up of 3 years, $38.1 \%$ of patients in the bicalutamide group and $31.8 \%$ in the placebo group discontinued the treatment. Adverse events were the most common reason for withdrawal from treatment in the bicalutamide group versus disease progression in the placebo group [22]. Gynecomastia and/or breast pain were the most frequent adverse events in the bicalutamide arm with almost 3 of 4 patients being affected [22]. These symptoms improved or re-

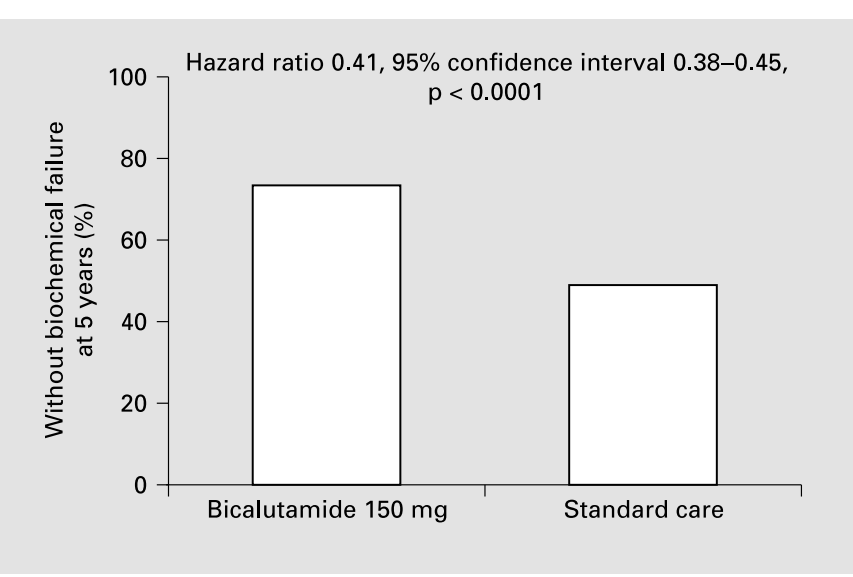

Fig. 2. Freedom from biochemical progression at 5 years [22].

solved after withdrawal of treatment in the majority of cases. Whereas breast pain disappeared in $84 \%$ of affected patients within 1 year after cessation of therapy, the resolution rate of gynecomastia depended on the duration of bicalutamide treatment with only $29 \%$ resolution in those patients who took the medication for more than 18 months [22]. At the time of the most recently published analysis [22], 363 patients in the bicalutamide arm and 559 patients in the placebo arm fulfilled the criteria of objective clinical progression (fig. 1). This reduction in the risk of clinical progression by $45 \%$ in the bicalutamide arm was highly significant (hazards ratio $0.58,95 \%$ confidence interval $0.51-0.66, \mathrm{p}<0.0001)$. This result needs to be qualified by emphasizing that in trial 23 , with its much more favorable risk profile, there was no detectable difference concerning objective progression at this time ( 83 events in the bicalutamide arm and 87 events in the placebo arm). Overall, the reduction in the risk was observed in the whole study population regardless of the primary (curative or noncurative) treatment. Subgroup analyses revealed a hazards ratio of $0.63(\mathrm{p}<0.001)$ for patients who had radical prostatectomy or radiotherapy and of 0.53 $(p<0.001)$ for those who did not undergo curative treatment [22]. As expected, the risk reduction was greater in patients with locally advanced disease and in those selected for watchful waiting [22]. Not unexpectedly, considering PSA progression, there was also a highly significant advantage in the bicalutamide arm (fig. 2). For a survival analysis, however, there were too few events observed up to the time of analysis, and a longer follow-up is needed to see whether the delayed clinical progression in the bicalutamide arm will translate into a survival advantage which is the most urgent question to be answered. 


\section{Conclusion}

Adjuvant treatment for prostate cancer has been shown to provide a survival advantage in patients with histopathologically proven lymph node involvement or with a high risk of microscopic spread. It is, however, still controversial whether a slightly delayed treatment (onset at PSA relapse) may be equally effective. Except for the above-mentioned high-risk patients, randomized trials on adjuvant treatment have so far revealed a delay of progression but no survival advantage in early prostate cancer. The maturation of data of large ongoing trials like the Bicalutamide Early Prostate Cancer Program will increase our knowledge base. However, further studies investigating the appropriate length of adjuvant hormonal therapy are also needed. Efforts are necessary to improve our understanding of factors influencing the survival of men with early prostate cancer.

\section{References}

1 Zincke H, Oesterling JE, Blute ML, Bergstralh EJ, Myers RP, Barrett DM: Long-term (15 years) results after radical prostatectomy for clinically localized (stage T2c or lower) prostate cancer. J Urol 1994;152:1850-1857.

2 Gerber GS, Thisted RA, Chodak GW, Schröder FH, Frohmüller HG, Scardino PT, Paulson DF, Middleton AW, Rukstalis DB, Smith JA, Ohori M, Theiss M, Schellhammer PF: Results of radical prostatectomy in men with locally advanced prostate cancer: Multi-institutional pooled analysis. Eur Urol 1997;32:385-390.

3 Bolla M: Adjuvant hormonal treatment with radiotherapy for locally advanced prostate cancer. Eur Urol 1999;35(suppl 1):23-26.

4 Barry MJ, Albertsen PC, Bagshaw MA, Blute ML, Cox R, Middleton RG, Gleason DF, Zincke H, Bergstralh EJ, Jacobsen SJ: Outcomes for men with clinically nonmetastatic prostate carcinoma managed with radical prostactectomy, external beam radiotherapy, or expectant management: A retrospective analysis. Cancer 2001;91:2302-2314.

5 Pilepich MV, Caplan R, Byhardt RW, Lawton CA, Gallagher MJ, Mesic JB, Hanks GE, Coughlin CT, Porter A, Shipley WU, Grignon D: Phase III trial of androgen suppression using goserelin in unfavourable prognosis carcinoma of the prostate treated with definitive radiotherapy - report of RTOG protocol 8531. J Clin Oncol 1997;15:1013-1021.

6 Lawton CA, Winter K, Murray K, Machtay M, Mesic JB, Hanks GE, Coughlin CT, Pilepich MV: Updated results of the phase III radiation therapy oncology group (RTOG) trial 85-31 evaluating the potential benefit of androgen suppression following standard radiation therapy for unfavorable prognosis carcinoma of the prostate. Int J Radiat Oncol Biol Phys 2001;49: 937-946.

7 Granfors T, Modig H, Damber JE, Tomic R: Combined orchiectomy and external radiotherapy versus radiotherapy alone for nonmetastatic prostate cancer with or without pelvic lymph node involvement: A prospective randomized study. J Urol 1998;159:2030-2034.

8 Arcangeli G, Saracino B, Micheli A, D'Angelo L, Pansadoro V, Cruciani E, Marchetti P: Radiotherapy with or without androgen deprivation in the treatment of localized adenocarcino- ma of the prostate. Am J Clin Oncol 1998;21: $1-5$

9 Hanks GE, Lu J, Machtay M, Venkatesan V, Pinover W, Byhardt R, Rosenthal SA: RTOG Protocol 92-02:A phase III trial of the use of long-term androgen suppression following neoadjuvant hormonal cytoreduction and radiotherapy in locally advanced carcinoma of the prostate (abstract). Proc ASCO 2000;19: 327a.

10 Bolla M, Collette L, Blank L, Warde P, Dubois JB, Mirimanoff RO, Storme G, Bernier J, Kuten A, Sternberg C, Mattelaer J, Lopez Torecilla J, Pfeffer JR, Lino Cutajar C, Zurlo A, Pierart M: Long-term results with immediate androgen suppression and external irradiation in patients with locally advanced prostate cancer (an EORTC study): A phase III randomised trial. Lancet 2002;360:103-106.

11 Zincke H, Bergstralh EJ, Larson-Keller JJ, Farrow GM, Myers RP, Lieber MM, Barrett DM, Rife CC, Gonchoroff NJ: Stage D1 prostate cancer treated by radical prostatectomy and adjuvant hormonal treatment. Cancer 1992; 70:311-323.

12 Seay TM, Blute ML, Zincke H: Long-term outcome in patients with pTxN+ adenocarcinoma of prostate treated with radical prostatectomy and early androgen ablation. J Urol 1998;159: 357-364.

13 Messing EM, Manola J, Sarosdy M, Wilding G, Crawford ED, Trump D: Immediate hormonal therapy compared with observation after radical prostatectomy and pelvic lymphadenectomy in men with node-positive prostate cancer. N Engl J Med 1999:341:1781-1788.

14 Prayer-Galetti T, Zattoni F, Capizzi A, Dal Moro F, Pagano F on behalf of the study group: Disease free survival in patients with pathological 'C stage' prostate cancer at radical retropubic prostatectomy submitted to adjuvant hormonal treatment (abstract). Eur Urol 2000; 38(suppl 4):504.

15 Zincke H, Lau W, Bergstralh, Blute ML: Role of early adjuvant hormonal therapy after radical prostatectomy for prostate cancer. J Urol 2001;166:2208-2215.
16 Wirth M, Frohmüller H, Marx F, for the study group: Adjuvant antiandrogenic treatment after radical prostatectomy in stage $\mathrm{C}$ prostate cancer - preliminary results of a randomized controlled multicenter trial (abstract). J Urol 1997;157(suppl): 1308.

17 Wirth MP, Weissbach L, Marx FJ, Heckl W, Jellinghaus W, Riedmiller $\mathrm{H}$, Noack $\mathrm{B}$, Froehner M: Prospective randomised trial comparing flutamide as adjuvant treatment versus observation after radical prostatectomy for stage pT3pN0 prostate cancer (abstract). J Urol 2003; 169:343.

18 Nair B, Wilt T, MacDonald R, Rutks I: Early versus deferred androgen suppression in the treatment of advanced prostatic cancer. Cochrane Database Syst Rev 2002;(1):CD003506.

19 Wirth MP, Froehner M: The value of endocrine therapy for early and locally advanced prostate cancer. Drugs Aging 2003;20:115124.

20 Early Breast Cancer Trialists' Collaborative Group: Tamoxifen for early breast cancer: An overview of the randomized trials. Lancet 1998;251:1451-1467.

21 Wirth M, Tyrrell C, Wallace M, Delaere KP, Sanchez-Chapado M, Ramon J, Hetherington J, Pina F, Heynes CF, Borchers TM, Morris T, Stone A: Bicalutamide (Casodex) $150 \mathrm{mg}$ as immediate therapy in patients with localized or locally advanced prostate cancer significantly reduces the risk of disease progression. Urology 2001;58:146-151.

22 See WA, Wirth MP, McLeod DG, Iversen P, Klimberg I, Gleason D, Chodak G, Montie J, Tyrrell C, Wallace DM, Delaere KP, Vaage S, Tammela TL, Lukkarinen O, Persson BE, Carroll K, Kolvenbag GJ; Casodex Early Prostate Cancer Trialist Group: Bicalutamide as immediate therapy either alone or as adjuvant to standard care of patients with localized or locally advanced prostate cancer: First analysis of the early prostate cancer program. J Urol 2002; 168:429-435.

23 See WA, McLeod D, Iversen P, Wirth M: The Bicalutamide Early Prostate Cancer Program. Demography. Urol Oncol 2001;6:43-47.

24 Wirth MP, Froehner M: Perspectives in adjuvant treatment of prostate cancer. Urol Int 2002;85:1-5. 